\title{
A Comparison of the Canning Quality of the Rico and the U.P.R. 3 Sweetpotatoes
}

\author{
F. Sánchez-Nieva, J. Benero, and M. A. González ${ }^{1}$
}

\section{INTRODUCTION}

The Puerto Rican canning industry has been processing, almost exclusively, sweetpotatoes of the U.P.R. 3 variety. It has been preferred for its attractive color, good flavor, firmness, and high $\mathrm{B}$ carotene content. Recently, Moscoso (1) ${ }^{2}$ developed a new variety of sweetpotato, the Rico, which is very similar to the U.P.R. 3, but which has the added advantage of giving higher yields. Since no information is available on the canning quality of this new variety it was decided to compare its behavior during processing, as well as the quality of the canned product, with that of the U.P.R. 3.

The canning of sweetpotatoes has been fully described by Woodroof, $e t$ al. (2) ${ }^{2}$, who recommended a process with 13 steps: Grading, washing and preheating, peeling, washing, acid-dipping, trimming, cutting and rinsing, filling, siruping, exhausting, closing, processing, and cooling. However, a more simple process is used in commercial practice in Puerto Rico.

The sweetpotatoes, after grading, are immediately peeled in lye without preheating, and no acid dip is used after peeling. Although it is recognized that heating before peeling is convenient to inactivate the enzyme system and to prevent discoloration ( $(3)$, and also that an acid dip should be used for similar purposes, as well as for removing traces of lye, it was decided not to use these two steps in canning the sweetpotato. This was because the objective of the tests was to compare the relative utility of the two above-mentioned varieties in the canning of sweetpotatoes in Puerto Rico, where heating before peeling and acid-dipping are not practiced commercially.

\section{EXPERIMENTAL PROCEDURE}

The two varieties of sweetpotatoes, the U.P.R. 3 and the Rico, were obtained from the Isabela Substation. They were harvested about $4 \frac{1}{2}$

${ }^{1}$ Respectively, Technical Director, Research Assistant in Chemistry, and Assistant Chemical Engineer, Food Technology Laboratory, Agricultural Experiment Station, University of Puerto Rico, Río Piedras, P.R. Acknowledgment: The authors wish to express their gratitude to A. Riollano and R. Abrams for supplying the sweetpotatoes used in this work, and to B. G. Capó for assistance given in the statistical interpretation of the data. Special recognition is given N. Nadal, A. García, M. Martínez, and B. García for conducting the analytical determinations used in this work, and to R. L. Fernández and A. Caballero for conducting the organoleptic tests.

${ }^{2}$ Italic numbers in parentheses refer to Iiterature Cited, p. 231-2. 
months after planting, graded for size, and processed immediately. Only roots ranging in size from $1 \frac{1}{2}$ to 2 inches in diameter were used.

The sweetpotatoes were processed on pilot-plant scale on a line with a capacity for processing 300 pounds per hour. The roots were washed in a rotary washer and peeled in 10 -percent lye at $210^{\circ} \mathrm{F}$. A rotary lye-peeler similar to the one described by Thurber and Bohne was used (4). From the lye-peeler the roots were discharged into a rotary washer provided with high-pressure water sprays to remove lye and loose peel. Trimming immediately followed peeling and washing. The roots were kept under water before and after trimming to prevent discoloration. The processed sweetpotatoes were packed in plain tin cans with C-enamel ends of 14-oz. fill-in weight per No. 2 can. Thirty-five-degree Brix sirup at $200^{\circ} \mathrm{F}$. was added and the cans were exhausted in a steam exhaust-box for 15 minutes to a center can temperature of $165^{\circ} \mathrm{F}$. After closing, the cans were retorted for 45 minutes at $240^{\circ} \mathrm{F}$. and cooled to $100^{\circ} \mathrm{F}$. The cooled cans were airdried and stored at room temperature.

\section{ANALYTICAL METHODS}

\section{ANALYSIS OF THE UNPROCESSED ROOTS}

Ten roots were selected at random and ground in a food-chopper. Individual samples were taken for moisture, starch, sugar, and B carotene determinations. This method of selection and preparation of samples has been shown to involve relatively small errors in sampling and in the chemical determinations ( 5 ).

For moisture determinations, duplicate samples of the ground pulp weighing about $10 \mathrm{gm}$. each were dried to constant weight in a vacuum oven at $70^{\circ} \mathrm{C}$. under a vacuum of $100 \mathrm{~mm}$. Loss in weight was calculated as percentage of moisture (6).

For determination of reducing and total sugars, 25 -gm. samples of the ground pulp were transferred to $250-\mathrm{ml}$. volumetric flasks, $115 \mathrm{ml}$. of $54.3-$ percent alcohol were added, and the mixture was heated in a steam bath for 1 hour. After cooling, 95-percent alcohol was added to make to volume, and the mixture filtered. Two-hundred-milliliter aliquots were evaporated on a steam bath to $20-30 \mathrm{ml}$. transferred to $100 \mathrm{ml}$. volumetric flasks, saturated neutral lead acetate solution was added, and the mixture was allowed to stand 15 minutes. The solution was diluted to mark with water and filtered. The filtrate was deleaded with $\mathrm{Na}_{2} \mathrm{CO}_{3}$ and filtered. Reducing sugars were determined in the filtrate without inversion. Total sugars as invert were determined after inversion with hydrochloric acid. Sugars were determined by the Munson and Walker procedure (7).

B carotene was determined in samples of the ground pulp by the Moore and Ely procedure, but using acetone as the extractant $(8,9)$. 
Starch was determined by the method described by Carter and Neubert (10) for the determination of starch in apples. The standard spectrophotometric curve was prepared using a Spectronic 20 at $590 \mathrm{~m} \mu$.

For total-acidity determination a $10 \mathrm{-gm}$. sample of the ground pulp was made into a slurry with distilled water and titrated with $0.1 \mathrm{~N} \mathrm{NaOH}$ to $\mathrm{pH} 8.1$ in a titrometer. Titratable acidity is expressed as percentage of anhydrous citric acid.

Color was measured in a Hunter Color and Color-Difference Meter as follows: A whole root was cut lengthwise in halves. Color was measured for the exposed flesh with the meter calibrated for $R_{d}$, $a$ and $b$, with a white standard. Readings from several roots of the same variety were averaged.

\section{ANALYSIS OF THE CANNED PRODUCT}

Two methods of sample preparation were tried: In one method the whole content of the can was disintegrated in a Waring blendor and samples of the slurry were taken for analysis. In the second method the liquid was drained and the drained sweetpotatoes made into a slurry in an electric blendor, and samples taken for analysis. Difference between samples in a lot was found to be so great that it was not possible to obtain reliable data for comparison purposes by either of the two methods. Therefore, no analytical data on the canned product have been included in this report.

\section{ORGANOLEPTIC TESTS}

The quality of the canned product was determined organoleptically by trained tasters from our own staff. Two methods were used to determine product quality and preference. By one method, a sample of processed sweetpotato was presented to the tasters in an air-conditioned testing booth under red light. Tasters were required to score the samples for tenderness, fibrous condition, flavor quality, sweetness, and off-flavors. The color of the sample was similarly scored under daylight. A 5-point scale was used for all criteria measured. Average scores for each factor were calculated and the difference between samples was statistically computed.

The pair test was used in the second method. A sample of each variety was presented to the tasters under the conditions described above. The tasters were requested to taste both samples and to indicate their preference on the basis of tenderness, fiber content, flavor, color, and appearance. Differences between the samples were determined by statistical analysis of the data.

\section{RESULTS}

COMPOSITION OF THE UNPROCESSED ROOTS

The analytical data on samples of raw roots are given in table 1. These values represent the average of four analyses of samples of each variety, 
harvested at different intervals during the season, but of approximately the same age. The Rico is higher in moisture and reducing total sugars than the U.P.R. 3, but lower in stareh and B carotene. Because of the higher moisture content of the Rico variety, when results are expressed on a dry basis, as in table 2, the Rico contains more starch than the U.P.R.

TABLE 1.-Chemical composition of raw roots of 2 sweetpotato varicties expressed on wet basis

\begin{tabular}{l|c|c}
\multicolumn{1}{c|}{ Constituent or color } & Rico & U.P.R. 3 \\
\hline & Percent & Percent \\
Moisture & 70.5 & 66.4 \\
Total acidity & .14 & .14 \\
Reducing sugars & 1.23 & .59 \\
Total sugars as invert & 4.70 & 3.80 \\
Starch & 24.10 & 26.70 \\
& Mg./100 gm. & Mg./100 gm. \\
B carotene & 9.40 & 11.80 \\
Hunter color & & 40.2 \\
Rd & 44.3 & 29.2 \\
a & 28.1 & 30.7 \\
b & 31.8 & \\
\hline
\end{tabular}

TABLE 2.-Chemical composition of raw roots of 2 sweetpotato varielies expressed on dry basis

\begin{tabular}{l|c|c}
\hline \multicolumn{1}{c|}{ Constituent } & Rico & U.P.R. 3 \\
\hline & Percent & Percent \\
Reducing sugars & 4.17 & 1.76 \\
Total sugars as invert & 15.90 & 11.30 \\
Starch & 83.00 & 78.00 \\
& $\mathrm{Mg} / 100 \mathrm{gm}$. & $\mathrm{Mg} .100 \mathrm{gm}$. \\
B carotene & 31.80 & 35.20 \\
\hline
\end{tabular}

3. Both varieties were found similar in total acidity and $\mathrm{pH}$. The color of both varieties was about the same. Small differences in the Hunter Color values in table 1 can be attributed to small difference in color between samples, as well as to variations in readings normal to the instrument.

\section{PROCESSING CHARACTERISTICS}

\section{Lye-Peeling}

Both varieties were peeled in 10 -percent lye at $210^{\circ} \mathrm{F}$. The time required for peeling was different for each variety. Usually a 6-minute treat- 
ment was enough to peel the U.P.R. 3, while the Rico required from 8 to 10 minutes. It was repeatedly ohserved that the U.P.R. 3 was easier to peel than the Rico. After lye-peeling it was very easy to remove all rag and excess lye from the U.P.R. 3 by washing with water sprays in a rotary washer. The peeled root was always found to be a bright yellow free from discoloration.

It was found to be very difficult to remove the peel completely from the Rico. The sweetpotato discharged from the rotary washer was invariably found to have discolored spots resulting from an incomplete removal of peel and lye. It was necessary to wash the roots by hand before trimming in order to remove the peel completely. It was also observed that every time the Rico was processed, fibrous bundles collected at the openings of the screen of the washer, requiring frequent washing with a high-pressure hose for their removal.

Peeling losses were found higher for the Rico. As can be seen in table 3

Table 3.-Percentage peeling and trimming losses, and root recovery, for raw roots of 2 sweelpotato varieties-average figures from 4 runs

\begin{tabular}{l|c|c}
\hline \multicolumn{1}{c|}{ Item } & Rico & U.P.R. 3 \\
\hline Peeling loss & 28.80 & 23.40 \\
Trimming loss & 14.40 & 14.20 \\
Recovery of roots for canning & 57.00 & 63.00 \\
\hline
\end{tabular}

losses during peeling and washing were found to be 23.4 percent for the U.P.R. 3 and 28.8 for the Rico. Higher peeling losses for the Rico suggested that this variety probably had a thicker peel and cortex than U.P.R. 3, but measurement of both varieties indicated the opposite. The Rico was found to have markedly thinner peel and cortex than the U.P.R. 3. It could be established that there was a better defined cortex in the U.P.R. 3 than in the Rico. The cortex of the U.P.R. 3 could be fairly easily separated from the storage parenchyma beneath by means of a knife, which was not possible with the Rico. The difference in behavior during lye-peeling and the higher peeling losses for the Rico can thus be attributed to the fact that the cortex in this variety cannot be easily separated from the tissue beneath, even after longer treatment with lye. This results in attack by lye of the parenchyma tissue, with subsequent discoloration.

\section{Trimming Losses}

Trimming losses were found similar for both varieties, as shown in table 3. Although, as previously mentioned, the difficult removal of the peel in the Rico variety resulted in surface discoloration, no trimming was 
necessary to remove the discolored tissue. Since only small quantities of sweetpotatoes were processed, it was an easy matter to remove this tissue by hand-washing the roots before trimming or cutting the ends. In commercial processing, however, it is expected that higher trimming losses would result with the Rico, as discolored tissue would have to be cut, since hand-washing would be impossible.

\section{Over-All Yields}

Higher peeling losses resulting from processing of the Rico reduced the yields of roots for canning about 6 percent when compared with yields obtained when processing the U.P.R. 3. However, since the Rico variety yielded about 3,200 pounds more per acre (1) than the U.P.R. 3, processing of the Rico would result in an over-all yield of 1,600 pounds of processed roots for canning in excess of that obtained with the U.P.R. 3. It should be noted that this increase in yield is expressed in terms of farm output instead of canned product. To the canner, processing of the Rico means lower yields of canned product per ton of roots processed, and therefore, the U.P.R. 3 is to be preferred. Since Rico yields better, it is suggested that the price to be paid by the canner for this variety be lower than that paid for the U.P.R. 3 in order to keep processing costs at a similar level. Otherwise canners will not benefit by processing the Rico, as no improvement in yields or quality can be expected to result when processing this variety.

\section{Siruping, Exhausting, and Cooking}

No difference could be observed between the two varieties during siruping, exhausting, and cooking. Neither of the two varieties was found to discolor appreciably during processing. Exhausting for 14 minutes to a can-center temperature of $160-165^{\circ} \mathrm{F}$. was found adequate to insure a good vacuum in the can. Processing for 60 minutes at $240^{\circ} \mathrm{F}$., as is generally recommended for Puerto Rican-type sweetpotatoes (11), was found detrimental to the product. When this processing time was used, both varietics became mushy and easily broke down during normal handling of the cans. All packs prepared in the course of this work were processed for 45 minutes at $240^{\circ} \mathrm{F}$. Heat-penetration measurements on the canned product, as well as bacterial counts, showed this process to be safe under the conditions prevailing during the pilot-plant processing of the packs. Processing for the time indicated resulted in a better quality product.

\section{QUALITY OF THE CANNED PRODUCT}

In table 4 are tabulated the results of the organoleptic tests when tasters were served single samples consisting of a single processed sweetpotato 
from which the sirup had been drained. All samples received similar ratings for the different quality factors, irrespective of variety. Statistical analysis of the data indicated that no difference could be detected by tasters between the two varieties.

In an attempt to determine more precisely where there was a difference in the quality of the canned Rico and U.P.R. 3 sweetpotatoes, a sample of

TABLE 4.-Quality of the canned product from 2 sweetpotato varieties as appraised on individual samples organoleptically

\begin{tabular}{|c|c|c|c|c|c|c|c|c|}
\hline \multirow{2}{*}{ Qunlity criteria } & \multicolumn{4}{|c|}{ U.P.R. 3 sample } & \multicolumn{4}{|c|}{ Rico sample } \\
\hline & A & B & c & $\mathbf{D}$ & $A^{\prime}$ & $\mathbf{B}^{\prime}$ & $\mathrm{C}^{\prime}$ & $\mathrm{D}^{\prime}$ \\
\hline Tenderness & 4.43 & 4.38 & 4.70 & 4.20 & 4.50 & 4.47 & 2.90 & 4.70 \\
\hline Fibrousness & 3.86 & 4.24 & 3.10 & 3.15 & 4.27 & 4.29 & 3.10 & 3.85 \\
\hline Sweetness & 4.57 & 4.90 & 4.40 & 4.20 & 4.07 & 4.24 & 3.40 & 4.65 \\
\hline Off-flavor & 5.00 & 4.85 & 4.90 & 4.95 & 4.67 & 4.62 & 4.60 & 5.00 \\
\hline Appearance & 3.83 & 3.58 & 4.00 & 3.52 & 4.33 & 3.90 & 3.90 & 4.48 \\
\hline Color & 3.71 & 4.65 & 3.70 & 3.48 & 3.46 & 3.65 & 3.70 & 3.67 \\
\hline Flavor & 3.93 & 4.24 & 3.80 & 3.65 & 4.13 & 3.71 & 3.10 & 4.30 \\
\hline Total score & 29.79 & 30.88 & 28.60 & 27.15 & 29.43 & 29.88 & 24.70 & 30.65 \\
\hline
\end{tabular}

TABLE 5.-Resulls of pair-test comparisons on canned sweetpotatoes of 2 varieties, showing percentage of tasters selecting sample for indicated quality criteria ${ }^{1}$

\begin{tabular}{|c|c|c|c|c|c|c|c|c|}
\hline Quality criteria & $\underset{A}{\text { Rico }}$ & $\underset{\dot{A}^{\prime}}{\text { U.P.R. }} 3$ & $\underset{\mathbf{B}}{\text { Rico }}$ & U.P.R. ${ }_{\mathbf{B}^{\prime}} 3$ & Rico & U.P.R. ${ }_{\text {C }^{\prime}}^{3}$ & $\underset{D}{\text { Rico }}$ & $\underset{\mathbf{D}^{\prime}}{\text { U.P.R. }} 3$ \\
\hline More tender & 50.0 & 50.0 & 38.1 & 61.9 & 20.0 & $80.0^{*}$ & $75.0^{*}$ & 25.0 \\
\hline Less fibrous & $83.3^{*}$ & 16.7 & 61.9 & 38.1 & 65.0 & 35.0 & 60.0 & 40.0 \\
\hline Better flavor & 56.6 & 46.4 & 28.6 & 71.4 & 10.0 & $90.0^{*}$ & 65.0 & 35.0 \\
\hline Better appearance & 62.4 & 37.6 & $88.2^{*}$ & 11.8 & 45.0 & 55.0 & 78.0 & 22.0 \\
\hline Better color & 62.4 & 37.6 & 82.4 & 17.6 & 50.0 & 50.0 & $100.0^{*}$ & \\
\hline Preferred & 60.0 & 40.0 & 38.1 & 61.9 & 15.0 & $85.0^{*}$ & $100.0^{*}$ & \\
\hline
\end{tabular}

$1 *=$ Significant difference between samples at 5-percent level.

each variety was presented to the tasters at the same time. They were required to indicate their preference for the different quality criteria.

The results of these tests are given in table 5 , in which the percentage of tasters selecting a sample is shown. Statistical analysis of the data shows that no difference could be found between samples $A-A^{\prime}$, except for fibrousness; the Rico was chosen as less fibrous, the results being significant at the

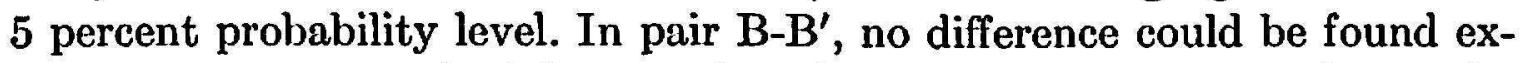
cept in appearance; the Rico was found better in appearance, the results being significant at the 5-percent level. In pair C-C ${ }^{\prime}$ the U.P.R. 3 was 
found to have better flavor and to be more tender while, in pair D-D', the Rico was preferred for better color, over-all quality, and tenderness.

Although it was possible to establish certain differences between the varieties in the pairs studied by the use of the pair test, no conclusive results were obtained to indicate that one variety was better than the other. The difference between varieties for some of the quality attributes was so small that it could hardly be detected in a pair test. It is to be expected then, that consumers would be unable to detect any difference in quality between varieties. It can be concluded that the quality of the sirup-packed sweetpotato of the Rico and U.P.R. 3 varieties is essentially the same.

\section{SUMMARY}

The processing and canning quality of the sweetpotato varieties U.P.R. 3 and Rico was studied. Unprocessed roots of the Rico variety were found higher in moisture and sugar than the U.P.R. 3, but the U.P.R. 3 was found to contain more B carotene. Processing losses for the Rico were 6 percent higher than for the U.P.R. 3. The higher processing losses for the Rico are caused by a higher loss during lye-peeling. There was very little difference in the quality of the sirup-packed potatoes of the two varieties. Tasters were unable to establish preference in regard to over-all quality of either.

\section{RESUMEN}

Se estudió el comportamiento de las variedades Rico y U.P.R. 3 durante el proceso de enlatado y se comparó la calidad del producto enlatado de ambas. La batata de la variedad Rico en su estado natural contiene más humedad y un porcentaje de azúcares reductoras e invertidas totales más alto que la variedad U.P.R. 3. Esta última, sin embargo, es más rica en caroteno B.

Cuando se elaboraron estas dos variedades, se pudo establecer que la variedad Rico sufre una pérdida mayor en peso al pelarse con soda que la variedad U.P.R. 3. El rendimento de batata elaborada por quintal de batata fresca fué 6 por ciento mayor en cuanto a la variedad U.P.R. 3.

\section{LITERATURE CITED}

1. Moscoso C., Agr. Fixp. Btn., U.P.R., Bul. 126, 1055.

2. Woodroof, J. G., DuPree, W. E., and Cocil, S. R., Ga. Agr. Jxp. Sta., Bul. N. S. $12,1955$.

3. Scott, L., Appleman, C. O., and Wilson, M., Univ. Md., Bul. A 33 (Tech) 1944.

4. Thurber, F. J., and Bohne, P. W., Food Industries 18 10-1, 1945.

5. ——, Southern Co-op. Series Bul. 30, 13-6, 1953.

6. Assn. Of. Agr. Chem., Washington, D. C., Official Methods of Analysis, 8th ed., $343,1955$. 
7. Ibid. 545-6.

8. Moore, L. A., and Ely, R., Ind. Eng. Chem. Anal. Ed. 13 600-1, 1941.

9. Assn. Of. Agr. Chem., Washington, D. C., Official Methods of Analysis, 8th ed., 816, 1955.

10. Carter, J. H., and Neubert, A. M., Agr. \& Food Chem. 2 (21) 1070-2, 1954.

11. National Canners Association, Bul. 261, 8th ed., 36, 1955. 